\title{
INTERDEPENDENCIES BETWEEN TYPES OF PRODUCTION COSTS AND THE OUTPUT IN THE PRODUCING AND PROCESSING OF MEAT AND MEAT PRODUCTS IN STARA ZAGORA AREA
}

\author{
O. Milev*, Iv. Georgiev \\ Department of Economics, Faculty of Economics, Trakia University, Stara Zagora, Bulgaria
}

\begin{abstract}
The purpose of this survey is to study the relationships and interdependencies between cost types and the level of production by product group.

Subject of the survey are companies from the food industry sector in the Stara Zagora region, with the object of producing and processing meat and meat products.

The method used in this study enables to analyze the changes in the average fixed, average variables, average total and marginal costs, how affect the marginal and average product.

As a result of these cost-production interdependencies, the critical points related to increasing, decreasing and negative return of costs of production of meat and meat products are identified and analyzed.
\end{abstract}

Key words: cost, quantitative interdependencies, average and marginal values, declining and rising return on expenditure, meat and meat products

\section{INTRODUCTION}

The food industry is a traditional sector for the Bulgarian economy. Various factors influence the production in the sector, part of which are related to the raw material base, the climate, the condition of the agrarian sector, the seasonality of production, the taste characteristics of the raw materials, and the other part - with the characteristics of the sector /the condition of the material basis, the potential for renovation and restructuring of the companies, the available human resources, the condition of infrastructure, the development of trade and distribution/.[5]

According to the Classification of Economic Activities /KID-2008/ "production and processing of meat; production of meat products without ready meals" as part of the production of food products is in section 10 of sector $\mathrm{C}$ of the processing industry. [4]

The empirical study is focused on the subsector Production and processing of meat and meat products and it covers 7 companies in the territory of Stara Zagora District, for the period

\footnotetext{
*Correspondence to: Oleg Milev, Faculty of Economics, Department of Economics, Trakia University - Stara Zagora, Student campus, 6000 Stara Zagora, Bulgaria, +359 42699 431, E-mail: milev@uni-sz.bg
}

2012 - 2016, which cover around $93 \%$ of all operating companies in this subsector of the food industry.

For greater detail, the sub-sector Production and processing of meat and meat products is divided in 3 groups:

The Production and the processing of fresh and chilled meat, covering a $40 \%$ share in the subsector; Production of frozen meat with a share of $18 \%$; Production of sausages and smoked meats with a share of $33 \%$.

The production factors are identified with the realization of the costs for their acquisition and use in the production process. This is aimed at the minimization of the invested funds, because the same are a function of the number of the manufactured products and the volume of production. [2]

The dependences between the types of costs and the amounts of manufactured products can be identified through the variable costs, which are a function of the production volume, as well as the Cost concept, searching for the relationship between cost increase $(\Delta \mathrm{VC}$, $\Delta \mathrm{TC})$ and production increase $(\Delta \mathrm{Q})$ and their optimization. The ratio of these two values $(\Delta \mathrm{VC} / \Delta \mathrm{Q}$ and $\Delta \mathrm{TC} / \Delta \mathrm{Q})$ gives the amount of the marginal costs $(\mathrm{MC})$ indicating the increase in the total costs (equal to the increase in the 
MILEV O., et al.

variable costs) for each unit of increase in the production. $[1,6]$

The essential characteristics of the average product (AP) and the marginal product (MP) are also subject to the present analysis. The average product indicates how many units of product are created by each unit of variable investment. [3]

The marginal product (MP) indicates the ratio of the increase in production $(\Delta \mathrm{TP})$ toward the cost increase $(\triangle \mathrm{VC})$, i.e. with how many units the production varies after each unit of variation in the factor.

\section{ANALYSIS OF THE \\ INTERDEPENDENCES BETWEEN COSTS AND PRODUCTION}

The quantitative measurements of the dependences between the types of costs and the production of fresh and chilled meat are indicated in Table 1.

Table 1. Interdependencies between types of production costs and the output in the production of fresh and chilled meat - 40\% share of production and processing of meat and meat products for the period 2012-2016

\begin{tabular}{|c|c|c|c|c|c|c|c|c|}
\hline \multirow[b]{2}{*}{ Years } & \multirow[b]{2}{*}{$\begin{array}{c}\text { Production } \\
\text { (tonnes) } \\
\text { Q=TR/P }\end{array}$} & \multirow[b]{2}{*}{$\begin{array}{c}\text { Fixed } \\
\text { costs } \\
\text { (thousand } \\
\text { BGN) } \\
\text { FC }\end{array}$} & \multirow[b]{2}{*}{$\begin{array}{l}\text { Variable } \\
\text { costs } \\
\text { (thousand } \\
\text { BGN) } \\
\text { VC }\end{array}$} & \multirow[b]{2}{*}{$\begin{array}{c}\text { Total } \\
\text { costs } \\
\text { (thousand } \\
\text { BGN) } \\
\text { TC }\end{array}$} & \multicolumn{3}{|c|}{ Average costs } & \multirow[b]{2}{*}{$\begin{array}{c}\text { Average } \\
\text { product } \\
\text { (thousand } \\
\text { BGN) } \\
\text { AP=Q/TC }\end{array}$} \\
\hline & & & & & $\begin{array}{c}\text { Fixed } \\
\text { costs } \\
\text { (thousand } \\
\text { BGN) } \\
\text { AFC=FC/ } \\
\text { Q }\end{array}$ & $\begin{array}{c}\text { Variable } \\
\text { costs } \\
\text { (thousand } \\
\text { BGN) } \\
\text { AVC=VC/ } \\
\text { Q }\end{array}$ & $\begin{array}{c}\text { Total } \\
\text { costs } \\
\text { (thousand } \\
\text { BGN) } \\
\text { ATC=TC/ } \\
\text { Q }\end{array}$ & \\
\hline 2012 & 7215 & 1782 & 29752 & 31534 & 0.25 & 4.12 & 4.37 & 0.23 \\
\hline 2013 & 7322 & 1907 & 30741 & 32648 & 0.26 & 4.20 & 4.46 & 0.22 \\
\hline 2014 & 10095 & 2960 & 38962 & 41922 & 0.29 & 3.86 & 4.15 & 0.24 \\
\hline 2015 & 10943 & 2634 & 46057 & 48691 & 0.24 & 4.21 & 4.45 & 0.22 \\
\hline 2016 & 12012 & 2345 & 47813 & 50158 & 0.20 & 3.98 & 4.18 & 0.24 \\
\hline
\end{tabular}

\begin{tabular}{|c|c|c|c|c|}
\hline Period & $\begin{array}{c}\text { Production } \\
\text { growth } \\
\text { (tonnes) } \\
\Delta Q\end{array}$ & $\begin{array}{l}\text { Total costs } \\
\text { growth } \\
\text { (thousand } \\
\text { BGN) } \\
\Delta \text { TC }\end{array}$ & $\begin{array}{c}\text { Marginal costs } \\
\text { (thousand } \\
\text { BGN) } \\
\text { MC }=\Delta T C / \Delta Q\end{array}$ & $\begin{array}{c}\text { Marginal } \\
\text { product } \\
\text { (thousand } \\
\text { BGN) } \\
M P=\Delta Q / \Delta T C\end{array}$ \\
\hline $2013 / 2012$ & 107 & 1114 & 10.41 & 0.10 \\
\hline $2014 / 2013$ & 2774 & 9274 & 3.34 & 0.30 \\
\hline $2015 / 2014$ & 847 & 6769 & 7.99 & 0.13 \\
\hline $2016 / 2015$ & 1069 & 1467 & 1.37 & 0.73 \\
\hline
\end{tabular}

The trends in the variation of the average and the marginal product are similar in the years of the analysed period. The average product varies in close margins for the period, as each unit of invested total cost creates from 0,22 to
0,24 units of product in the group "fresh and chilled meat". This is an argument for a guaranteed increasing return of the costs for the period, without fluctuations. 
MILEV O., et al.

What is positive in the group "fresh and chilled meat", is the sustainable growth trend of the marginal product, as its increase for each unit of cost increase is from 0,10 to 0,73 units of increase in production at the end of the period. The total costs for the period logically follow the trend of the variable costs, and the average fixed costs vary in close margins, by years $(0,20$ to 0,29 thousand leva(BGN)/ton), by reason of close ratios between the growth of the fixed costs and the growth rate of the production. The trends in the variation of the average and the marginal product are illustrated in Chart 1, Panel "B".

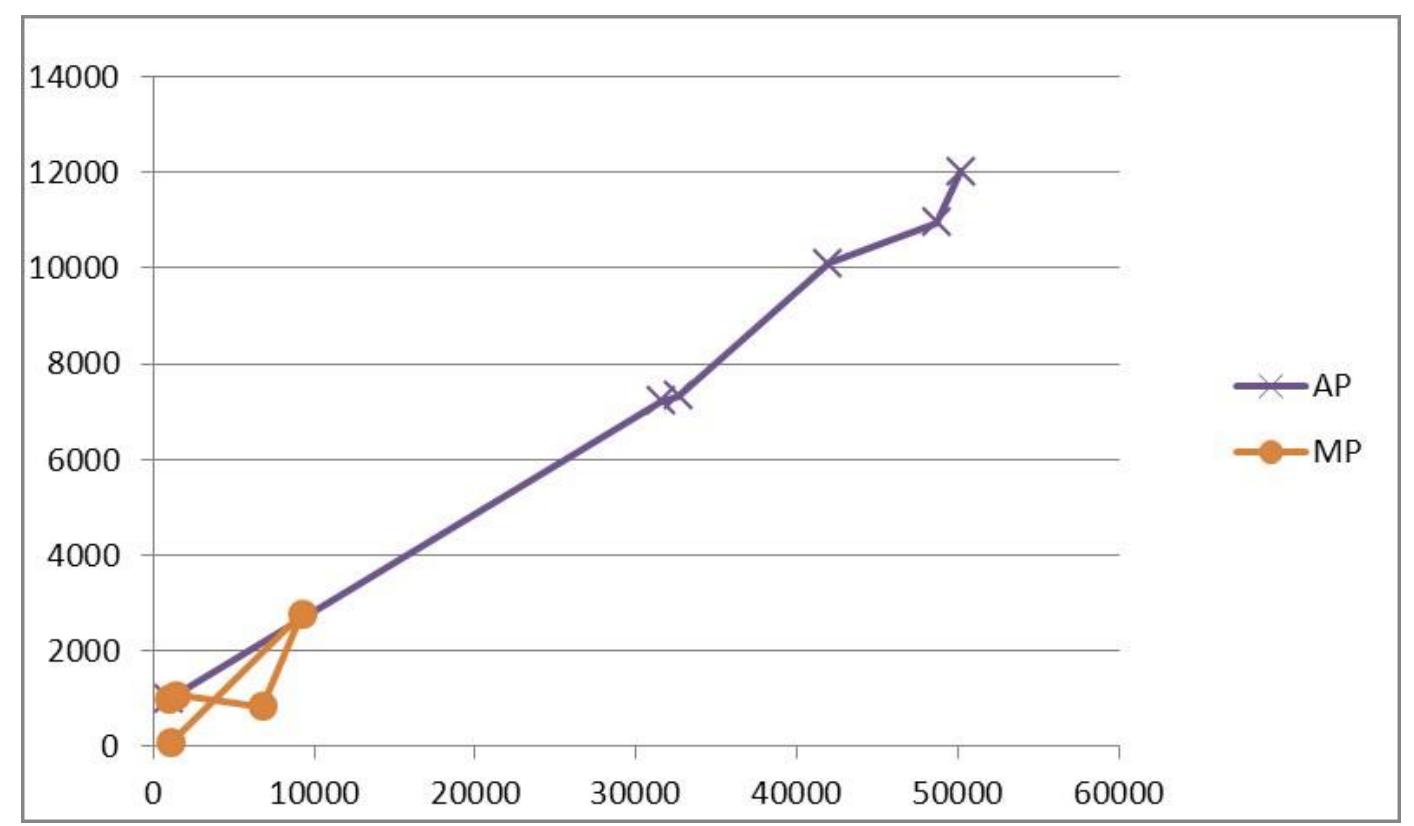

Chart 1. Fresh and chilled meat for the period 2012 - 2016, Panel "B"

Despite the highest level of the variable cost of the production in 2016, the average variable costs are at one of their lowest levels for the period (3,98 thousand leva(BGN)/ton), by reason of the highest level for production of fresh and chilled meat, by the group of companies for the period.

The marginal costs are the lowest at the end of the analysed period - year 2016, when the marginal product has the highest value. In this year, the marginal costs are nearly seven times lower than at the beginning of the period. A unit of increase in the production "fresh and chilled meat" is created by an increase in the total costs of just 1,37 thousand leva (BGN) per ton. The main reason for the indicated variations in the interdependence "costsproduction" is the significant growth rate of the production of fresh and chilled meat at a significantly lower growth rate of the costs. /Chart 1, Panel "A"/

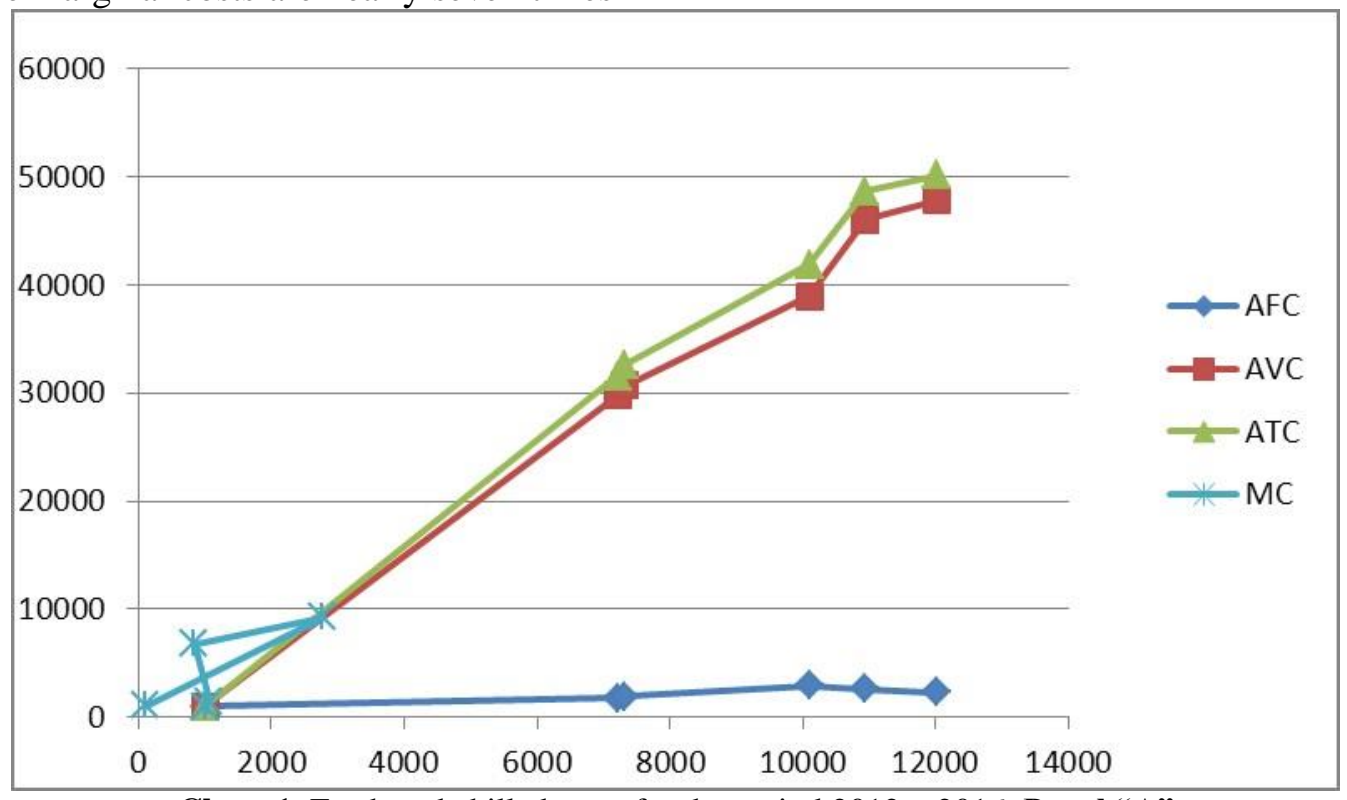

Chart 1. Fresh and chilled meat for the period $2012-2016$, Panel "A" 
MILEV O., et al.

An almost doubled growth of production for the period is present in the group of companies in the activity "meat and meat products", offering frozen meat. The average product is in close margins, as a unit of cost forms a production from 0,28 to 0,31 thousand leva (BGN). The average fixed costs have a longterm trend of reduction for the period 20122016, as for the last year, the fixed cost per ton of frozen meat is only 0,16 thousand leva(BGN). Such is the trend of the average variables and the average total costs, which has an insignificant increase for 2016. The reason is the increased amount of the variable costs together with a reduction (although it is insignificant) of the production volume.
The minimum of the marginal costs, forming the threshold of the diminishing return of the same, is the period 2014-2015, after which, the marginal costs and the marginal product become negative. The reason for that is the negative increase in production in 2016 in comparison to 2015 within an insignificant positive increase in the total costs. As a result, a unit of increase in the costs, creates a negative increase in production of 0,12 thousand leva (BGN).

The interdependences between the costs and the production in the case of the frozen meat are indicated in Table 2.

Table 2. Interdependencies between types of production costs and the output in the production of frozen meat - 18\% share of production and processing of meat and meat products for the period 20122016

\begin{tabular}{|c|c|c|c|c|c|c|c|c|}
\hline \multirow[b]{2}{*}{ Years } & \multirow[b]{2}{*}{$\begin{array}{c}\text { Production } \\
\text { (tonnes) } \\
Q=T R / P\end{array}$} & \multirow[b]{2}{*}{$\begin{array}{c}\text { Fixed } \\
\text { costs } \\
\text { (thousand } \\
\text { BGN) } \\
\text { FC }\end{array}$} & \multirow[b]{2}{*}{$\begin{array}{c}\text { Variable } \\
\text { costs } \\
\text { (thousand } \\
\text { BGN) } \\
\text { VC }\end{array}$} & \multirow[b]{2}{*}{$\begin{array}{c}\text { Total } \\
\text { costs } \\
\text { (thousand } \\
\text { BGN) } \\
\text { TC }\end{array}$} & \multicolumn{3}{|c|}{ Average costs } & \multirow[b]{2}{*}{$\begin{array}{c}\text { Average } \\
\text { product } \\
\text { (thousand } \\
\text { BGN) } \\
\text { AP=Q/TC }\end{array}$} \\
\hline & & & & & $\begin{array}{c}\text { Fixed } \\
\text { costs } \\
\text { (thousand } \\
\text { BGN) } \\
\text { AFC=FC/ } \\
\text { Q }\end{array}$ & $\begin{array}{c}\text { Variable } \\
\text { costs } \\
\text { (thousand } \\
\text { BGN) } \\
\text { AVC=VC/ } \\
\text { Q }\end{array}$ & $\begin{array}{c}\text { Total } \\
\text { costs } \\
\text { (thousand } \\
\text { BGN) } \\
\text { ATC=TC/ } \\
\text { Q }\end{array}$ & \\
\hline 2012 & 3949 & 802 & 13388 & 14190 & 0.20 & 3.39 & 3.59 & 0.28 \\
\hline 2013 & 3988 & 858 & 13833 & 14691 & 0.22 & 3.47 & 3.68 & 0.27 \\
\hline 2014 & 5440 & 1332 & 17533 & 18865 & 0.24 & 3.22 & 3.47 & 0.29 \\
\hline 2015 & 6861 & 1185 & 20726 & 21911 & 0.17 & 3.02 & 3.19 & 0.31 \\
\hline 2016 & 6781 & 1055 & 21516 & 22571 & 0.16 & 3.17 & 3.33 & 0.30 \\
\hline
\end{tabular}

\begin{tabular}{|c|c|c|c|c|}
\hline Period & $\begin{array}{c}\text { Production } \\
\text { growth } \\
\text { (tonnes) } \\
\Delta Q\end{array}$ & $\begin{array}{l}\text { Total costs } \\
\text { growth } \\
\text { (thousand } \\
\text { BGN) } \\
\Delta \text { TC }\end{array}$ & $\begin{array}{c}\text { Marginal costs } \\
\text { (thousand BGN) } \\
\text { MC }=\Delta T C / \Delta Q\end{array}$ & 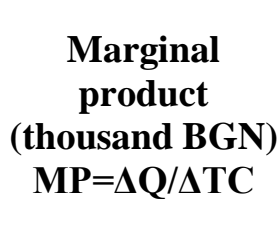 \\
\hline $2013 / 2012$ & 40 & 501 & 12.53 & 0.08 \\
\hline $2014 / 2013$ & 1452 & 4174 & 2.87 & 0.35 \\
\hline $2015 / 2014$ & 1421 & 3046 & 2.14 & 0.47 \\
\hline $2016 / 2015$ & -80 & 660 & -8.25 & -0.12 \\
\hline
\end{tabular}

The lowest average fixed costs, average variable costs and logically as a result, the 270 lowest cost value per ton of frozen meat in 2015, are in the amount of 3,19 thousand 
MILEV O., et al.

leva(BGN) per ton, which is a prerequisite for the highest marginal product and the lowest marginal cost for the period 2014-2015.
For sausages and smoked meats with a share of $33 \%$ in the activity "meat and meat products", the interdependences between the costs and the production are indicated in Table 3.

Table 3. Interdependencies between types of production costs and the output in the production of sausages and smoked meats - 33\% share of production and processing of meat and meat products for the period 2012-2016

\begin{tabular}{|c|c|c|c|c|c|c|c|c|}
\hline \multirow[b]{2}{*}{ Years } & \multirow[b]{2}{*}{$\begin{array}{c}\text { Production } \\
\text { (tonnes) } \\
Q=T R / P\end{array}$} & \multirow[b]{2}{*}{$\begin{array}{c}\text { Fixed } \\
\text { costs } \\
\text { (thousand } \\
\text { BGN) } \\
\text { FC }\end{array}$} & \multirow[b]{2}{*}{$\begin{array}{c}\text { Variable } \\
\text { costs } \\
\text { (thousand } \\
\text { BGN) } \\
\text { VC }\end{array}$} & \multirow[b]{2}{*}{$\begin{array}{c}\text { Total } \\
\text { costs } \\
\text { (thousand } \\
\text { BGN) } \\
\text { TC }\end{array}$} & \multicolumn{3}{|c|}{ Average costs } & \multirow[b]{2}{*}{$\begin{array}{c}\text { Average } \\
\text { product } \\
\text { (thousand } \\
\text { BGN) } \\
\text { AP=Q/TC }\end{array}$} \\
\hline & & & & & 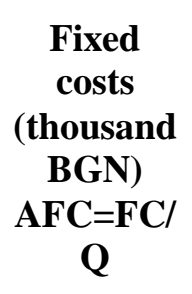 & $\begin{array}{c}\text { Variable } \\
\text { costs } \\
\text { (thousand } \\
\text { BGN) } \\
\text { AVC=VC/ } \\
\text { Q }\end{array}$ & $\begin{array}{c}\text { Total } \\
\text { costs } \\
\text { (thousand } \\
\text { BGN) } \\
\text { ATC=TC/ } \\
\text { Q }\end{array}$ & \\
\hline 2012 & 5699 & 1470 & 24546 & 26016 & 0.26 & 4.31 & 4.57 & 0.22 \\
\hline 2013 & 5789 & 1573 & 25361 & 26934 & 0.27 & 4.38 & 4.65 & 0.21 \\
\hline 2014 & 7991 & 2443 & 32143 & 34586 & 0.31 & 4.02 & 4.33 & 0.23 \\
\hline 2015 & 8090 & 2173 & 37997 & 40170 & 0.27 & 4.70 & 4.97 & 0.20 \\
\hline 2016 & 8615 & 1935 & 39446 & 41381 & 0.22 & 4.58 & 4.80 & 0.21 \\
\hline
\end{tabular}

\begin{tabular}{|c|c|c|c|c|}
\hline Period & $\begin{array}{c}\text { Production } \\
\text { growth } \\
\text { (tonnes) } \\
\Delta Q\end{array}$ & $\begin{array}{c}\text { Total costs } \\
\text { growth } \\
\text { (thousand } \\
\text { BGN) } \\
\Delta \text { TC }\end{array}$ & $\begin{array}{c}\text { Marginal costs } \\
\text { (thousand } \\
\text { BGN) } \\
\text { MC }=\Delta T C / \Delta Q\end{array}$ & $\begin{array}{c}\begin{array}{c}\text { Marginal } \\
\text { product } \\
\text { (thousand } \\
\text { BGN) }\end{array} \\
M P=\Delta Q / \Delta T C\end{array}$ \\
\hline 2013 / 2012 & 90 & 918 & 10.20 & 0,10 \\
\hline $2014 / 2013$ & 2202 & 7652 & 3.48 & 0.29 \\
\hline 2015 / 2014 & 99 & 5584 & 56.40 & 0.02 \\
\hline $2016 / 2015$ & 525 & 1211 & 2.31 & 0.43 \\
\hline
\end{tabular}

There is a growth of production of sausages and smoked meats for the period, accompanied by an adequate growth of the variable and total costs. The average variable costs and the cost value for the group of companies are the lowest in 2014. Logically, the average product in the same year has the highest value, as every 1000 leva/BGN of total cost invested in production creates 0,23 tons of produced sausages and smokes meats. The marginal product is the highest in 2016/2015, when for a unit of increase of the total cost, the variable cost creates 0,43 tons of production, consisted in sausages and smoked meats. Logically, the marginal cost for the same period is the lowest, as for each ton of increase in production, the increase in costs is only 2,31 thousand leva (BGN).

The graphic expression of the quantitative interdependences for sausages and smoked meats represents the indicated relationship between the marginal quantities. The maximal point of the marginal product corresponds to the lowest point of the marginal cost, where a unit of increase in production of sausages and smoked meats is achieved with the lowest increase in the variable costs.

The point, where the marginal cost becomes equal or close in value to the average total cost, 
is where the criterion for the minimal value of the cost value is created. Thus, for the studied period in 2014/2013, when the marginal cost is 3,48 thousand leva (BGN), the production cost for these products/sausages and smoked meats/ is the lowest for the whole five-year period of study (4,33 thousand leva(BGN) per ton).

\section{CONCLUSION}

During the analysis of the interdependences between the costs and the production in the three examined groups of sub-sector Production and processing of meat and meat products of the food industry, it may be noted that when reducing the average total costs, the average product increases. Logically, the variation of the total costs to follows the trend of variation of the variable costs. The increase in the latter is adequate to the variation of the production for the period. This trend is also maintained in the marginal costs related to the marginal product.

The reason for the increasing costs in a unit of production (variable and total costs) might be sought in the growth of prices of the production factors in the analysed groups on the one hand, as well as in other directions related to the capital structure of the production, strength, direction and reserves, which contain the factors measured through the indicators for total and individual factor influence.

\section{REFERENCES}

1. Cobb, C.W. and Douglas, P. H., A theory of production, American Economic Review, 1998

2. Georgiev, Iv., Agrarna ikonomika, Kota, Stara Zagora, 2007

3. Horngren, C., G. Foster, Cost Accounting: A Managerial Emphasis, Prentice-Hall International Editions, 1991.

4. Nacionalen statisticheski institut, Klasifikacia na ikonomicheskite deinosti, (KID-2012), Sofia 2012.

5. Totev, S., Integracionni procesi I regionalni razlichia - Evropeiski I nacionalni izmerenia, IU na BAN, Sofia, 2008.

6. Welsch, G. A., R. W., Hilton, Budgeting, Profit planning and control, 54h ed. Prentice-Hall, Inc., Englewood, 1988. 